\title{
Who does Greenpeace India represent?
}

DOI:

10.1163/19426720-02504004

\section{Document Version}

Accepted author manuscript

Link to publication record in Manchester Research Explorer

\section{Citation for published version (APA):}

Thrandardottir, E., \& Mitra, S. G. (2019). Who does Greenpeace India represent? Placing effective limits on the power of INGOs. Global Governance, 25(4), 587-619. https://doi.org/10.1163/19426720-02504004

\section{Published in:}

Global Governance

\section{Citing this paper}

Please note that where the full-text provided on Manchester Research Explorer is the Author Accepted Manuscript or Proof version this may differ from the final Published version. If citing, it is advised that you check and use the publisher's definitive version.

\section{General rights}

Copyright and moral rights for the publications made accessible in the Research Explorer are retained by the authors and/or other copyright owners and it is a condition of accessing publications that users recognise and abide by the legal requirements associated with these rights.

\section{Takedown policy}

If you believe that this document breaches copyright please refer to the University of Manchester's Takedown Procedures [http://man.ac.uk/04Y6Bo] or contact uml.scholarlycommunications@manchester.ac.uk providing relevant details, so we can investigate your claim.

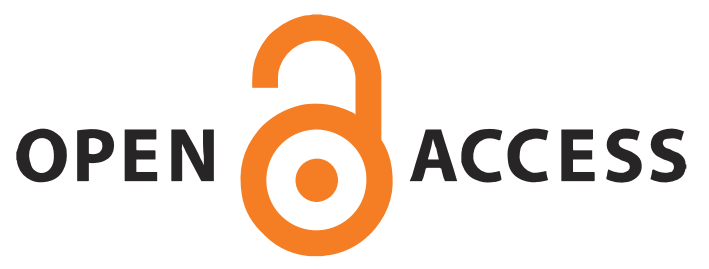




\title{
Who Does Greenpeace India Represent? Placing Effective Limits on the Power of INGOs
}

\author{
Erla Thrandardottir, Global Development Institute, University of Manchester \\ Susanna G. Mitra, Ramaiah Public Policy Centre, Bangalore
}

\begin{abstract}
The global governance literature is increasingly concerned with questions regarding the purpose of global governance and the sources of power in world politics. One strand of this debate centers on nongovernmental organizations and to what extent their role in global politics and policy processes is legitimate. This article uses Greenpeace India as an instructive case study to analyze the legitimacy problems facing international nongovernmental organizations (INGOs) campaigning on a global policy platform in the context of domestic politics. The article argues that the undertheorization of INGOs' agency as global actors is likely to reproduce processes of structural delegitimation that maintain a discrepancy between two of their legitimacy constructs. This is exemplified in questions about their representativeness and restrictive regulatory frameworks that undermine their legality. This article proposes that developing a more nuanced empirical understanding of the endogenous and exogenous limits of INGOs' power can help bridge the theoretical gap between their global and local agencies.
\end{abstract}

Keywords: Legitimacy, Global Governance, Energy Policy, Regulation, Foreign Funding, FCRA

\section{Introduction}

One of the key challenges that global governance regimes are facing today is the complexity of boundaries, where overlapping interests of private and public authority are "increasingly blurred through multi-actor initiatives," making it difficult to locate "the 'global' in global governance."1 One of the consequences of such complex governance arrangements is a gridlock where issues, such as environmental problems, become trapped in mechanisms that function as structural constraints preventing multiactor coordination. ${ }^{2}$ However, if complex multiactor initiatives are creating a post-Cold War legacy of "unmanaged globalization" with "corrosive effects" on domestic politics

\footnotetext{
${ }^{1}$ Coen and Pegram 2018.

2 Hale, Held, and Young 2013.
} 
threatening core interests of national governments, ${ }^{3}$ states in the Global South are responding by asking private global actors: Whose interests do you represent? And how are these accounted for? These questions are especially pertinent when posed in a context where the power of international nongovernmental organizations (INGOs) is perceived as a political threat to national interests. In the nongovernmental organization (NGO)literature, this problem can be seen in the transmission of global policy to the local level, typically characterized by a process where a global policy initiative is conceived of and funded in the Global North and then implemented in the Global South.

As INGOs are often the actors at the implementation end of global policy initiatives, ${ }^{4}$ they are also the ones facing this pushback from states in the Global South. INGOs such as environmental and human rights campaign groups are facing a major clampdown worldwide as a wave of countries pass restrictive laws to curtail their activities. ${ }^{5}$ Although INGOs' power in world politics has been expanding and deepening, to a point where they are championed as de facto representatives of various global and local publics, ${ }^{6}$ this rise in prominence has also been coupled with difficult questions about legitimacy; especially, who or what INGOs represent as private actors. ${ }^{7}$ With the rise of India and China as new powers, the voices of those raising these questions have become louder and possibly more aggressive, especially in terms of how to place effective limits on INGOs' power ${ }^{8}$ in an increasingly politicized interface between domestic and international authorities. ${ }^{9}$ In India, this has manifested itself in the government characterizing foreign-funded INGOs as "anti-national,"10 echoing similar sentiments raised against INGOs in Hungary, Turkey, and elsewhere, that focus on INGOs as being foreign funded, unrepresentative, and elitist. ${ }^{11}$

This article contributes to this debate on political representation in global governance by explaining a discrepancy between representation and legality in INGOs' legitimation

\footnotetext{
${ }^{3}$ Hale and Held 2018.

${ }^{4}$ Lindblom 2005, 487-509, 525; Lake and McCubbins 2006.

5 International Center for Not-for-Profit Law 2016, 19; 2018, 18.

6 Lang 2012; UN 2004; Corry and Stoker 2017; Ellis 2010; Lipschutz 1992; Keck and Sikkink 1998.

${ }^{7}$ Edwards and Hulme 1995; Lister 2003; Peruzzotti 2006.

8 Collingwood 2006.

${ }^{9}$ Avant, Finnemore, and Sell 2010; Lake 2010, 608; Zürn 2018.

10 Intelligence Bureau 2014a, 2014b.

${ }^{11}$ Christensen and Weinstein 2013; Rutzen 2015.
} 
through a case study of Greenpeace India (GPIN). When localizing its global Energy Revolution campaign, Greenpeace's strategy was to mobilize domestic constituents in India around an international environmental norm and, thus, aim to influence domestic policy debates on coal exploitation. As an exercise in global norm compliance, and viewed through the prism of global and local boundaries, Greenpeace's attempt at political socialization was unsuccessful and met with strong resistance from the Government of India (GoI). Instead of rallying support for a global anticoal norm, it faced local delegitimation of its authority and legal barriers resulting in the temporary closure of its Indian office. We use two frames, one endogenous and one exogenous, to describe the delegitimation process and to explain how it undermines the legitimacy of INGOs. We argue that the problems of INGOs' representativeness are rooted in the undertheorization of their agency as global actors. The corollary of this is structural delegitimation processes that reproduce, and maintain, a discrepancy between INGOs' representativeness and legality. If unresolved, INGOs will continue to face legitimacy challenges on these two fronts, especially from states in the Global South. This, in turn, fuels the politicization of the interface between global and domestic authorities in the governance of global issues such as the environment.

In short, we begin this article by outlining the theoretical context to show how INGOs' agency is being politicized and how this raises questions about representation when global issues are being localized. We then describe the background and rationale for the case study using India's energy policy and Greenpeace's Energy Revolution campaign to demonstrate the politicization of the interface between the global and the local, where domestic policy has become not only a target of such campaigns, but also a platform for embedding global values. We then use the case study to explain the limits of Greenpeace's power by applying two analytical frames to highlight a discrepancy in its legitimation. The first frame focuses on the endogenous limits of its global agency by looking at Greenpeace's internal organization of power as a measure of its representativeness. The second frame focuses on the exogenous limits of its global agency by analyzing the Foreign Contribution (Regulation) Act (FCRA) 2010 as a structural barrier to Greenpeace's legitimacy. We conclude the article by reflecting on the wider effects this may have on global civil society. 


\section{INGOs as Political Actors}

As INGOs' roles are both widening and growing, some scholars argue that it is important that we start accepting not only that INGOs are powerful actors in the political landscape, but also the inherent political nature of INGOs. ${ }^{12}$ Despite public acknowledgment of INGOs' authority and influence in world politics, there is a lack of theoretical grounding for their agency, a problem that feeds into a wider dilemma of political representation and authority in global governance. ${ }^{13}$ To understand the discrepancy in Greenpeace's legitimation as a powerful actor in global governance, it is necessary to start by outlining the politicization of INGOs' role in world politics.

The relationship between INGOs and the state has been theorized in international relations and development studies in several different ways. A common distinction to draw is between top-down or bottom-up approaches, ${ }^{14}$ or to conceptualize their legitimate role on a sliding scale with different degrees of political engagement. ${ }^{15}$ How we understand INGOs' relationship with states matters for how we theorize their influence on the political process. What has made this relationship more complex is INGOs' recent restructuring and growth in the Global South in response to pressures emanating from a changing world order. ${ }^{16}$ If INGOs previously worked inside paradigms that explained their behavior toward states as auxiliary-that is, working toward the same goal as the state in delivering services within a utilitarian framework ${ }^{17}$ - they now have a more complex and multilayered interaction with sites of political authority. As countries in the Global South, especially India and China, challenge the norms and structure of the international order, INGOs have become a target in debates about what counts as legitimate global authority.

In response, INGOs have made a concerted effort to restructure their organizations as more relevant and grounded in the local political realities in the Global South to hedge against these criticisms of global elitism and lack of accountability to beneficiaries. This includes moving coordinating offices to countries such as South Africa, China, and India as well as investing considerable resources of their global funds to establish national

\footnotetext{
12 Corry and Stoker 2017; Dellmuth and Tallberg 2017.

13 Hofferberth 2018, 4.

14 Reimann 2006; Walton et al. 2016.

15 Thrandardottir 2015

16 BOND 2014.

17 Thrandardottir 2015; Brown 2008.
} 
organizations with local legitimacy. Despite these efforts, the pushback from states persists and, instead of seeing INGOs as a welcome addition to an expanding pool of actors in global governance, their role is often viewed with suspicion. There are two things that states point out repeatedly as being problematic: representation and foreign funding. INGOs that originate from and still have coordinating offices in the Global North and whose resources are mainly international are charged with representing norms of a global elite with agendas that run counter, if not directly opposed, to those of national political representatives. As such, the legitimacy perspective has shifted from seeing INGOs as auxiliaries to viewing them as a political opposition.

Thus, what used to be a relatively straightforward or settled political question about where power is located has turned into an open-ended normative question about legitimacy and authority of different actors in global governance. If we accept that globalization has institutionalized multiple private authorities in global governance without credible political authority, such as epistemic and auxiliary communities, the literature is now tasked with answering more fundamental questions about the nature of their political authority and how and where to draw the boundaries for actors such as INGOs. ${ }^{18}$ In looking at the responses in the literature, one can discern three theoretical developments about how to limit the power of INGOs as global actors. One is a chorus of scholars arguing that civil society needs stronger theoretical roots and frameworks as international actors because they are continuing to grow, not only in numbers but also in influence. ${ }^{19}$ A second, more circumspect, argument points to INGOs' power and influence as being made up of "vanilla victories"; although INGOs are important and influential, they pay a heavy price for their seat at the high table by way of concessions and compromises on global policy issues. ${ }^{20}$ The third theoretical development points to a more hostile trend, where scholars are observing outright antagonism to INGOs' global agency, including the implementation of restrictive legal barriers. ${ }^{21}$

One of the reasons why the representation question has become so central, especially in the Global South, is a perception that INGOs' political power has been elevated by

\footnotetext{
18 Zürn 2017, 279; 2018.

${ }^{19}$ Corry and Stoker 2017; Hofferberth 2018; UN 2018.

20 Stroup and Wong 2017.

${ }^{21}$ Moore and Rutzen 2011; Rutzen 2015.
} 
globalization and can now rival those of elected representatives. ${ }^{22}$ As Issa Shivji argues, INGOs are highly political animals that perpetuate a myth about representing the poor in policy-making processes; processes that are inherently political about "which interest is being served." But he continues, instead of facilitating people's access to the policy process, INGOs have seemingly taken their place in it with presumptuous claims about representation. ${ }^{23}$ In the case of Greenpeace, this perceived transgression of private global authority into national politics caused a paradigmatic regulatory shift in India from a permissive to a restrictive framework that triggered a delegitimation process used to demarcate a boundary between a functional authority of globally represented interests and a domestic authority of democratically represented interests. The new regulation highlighted the rising tension between INGOs as global political actors and the government of a rising power that was using law to curb the authority of INGOs. Traditionally, INGOs in India have been regulated by the Societies Registration Act 1860 (SRA). However, the FCRA is increasingly being used to monitor the foreign funding of INGOs. The shift was perceived as a hostile structural barrier by INGOs where the government was using legality to undermine their legitimacy by tying representation to foreign funding to justify a more restrictive INGO legal framework.

We argue that to overcome such tensions in a politicized interface between global and domestic authorities, it is necessary not only that INGOs' agency be grounded in theory, ${ }^{24}$ but also to define the parameters of their global representativeness in what we call a narrow agency, which is our first proposition in explaining the discrepancy in their legitimacy. The second proposition focuses on how legality as a legitimacy construct is used to undermine INGOs' global authority in a national context. We draw on David Beetham's theory of legitimation. His theory explains the structure of legitimacy as providing "moral grounds for compliance or cooperation" in any given power relationship where the ultimate goal is to maintain order and stability. ${ }^{25}$ The levels or criteria Beetham defines as necessary prerequisites for political legitimacy are: 1) conformity to rules that express legality; 2) justifiability of the rules with reference to shared beliefs by those governing and those being governed by the rules; and 3) evidence

\footnotetext{
${ }^{22}$ Fukuyama 2015, 486, 503; Vedder 2007.

${ }^{23}$ Shivji 2007, 57-58.

${ }^{24}$ Hofferberth 2018, 4.

${ }^{25}$ Beetham [1991] 2013, 16.
} 
of expressed consent by those subject to the rules. ${ }^{26}$ Applying his theory to analyze INGOs' power, we focus on the first and third criteria because a considerable literature exists that discusses the second criterion while less research exists on the legality and representation dimensions of INGOs' power.

We demonstrate this analysis empirically in a case study on Greenpeace in India using two analytical frames to explore the boundaries of political representation where a global issue (environment) is being campaigned on locally (anticoal) in the context of national politics (energy policy). The first frame is endogenous and explains the limits of Greenpeace's agency in terms of representation that, once undermined or politicized, can trigger a process of delegitimation. The second frame is exogenous and explains how domestic regulation functions as a structural barrier for Greenpeace's global agency in terms of legality that triggered a process of delegitimation. The analytical frames show how vulnerable INGOs' legitimacy is to structural delegitimation processes, a problem we argue is derived from their undertheorized agency that maintains this discrepancy between representation and legality and, thus, continues to undermine their global legitimacy. For Greenpeace, this led to loss of social legitimacy and the temporary closure of Greenpeace’s India office.

As a rising power, India is an instructive example for these challenges that INGOs face as global actors. Despite a long-standing history of engaging with INGOs, ${ }^{27}$ the NGO-state relationship has often been an uneasy one with long-held suspicion over INGOs' role as global actors, whether framed in terms of corruption, foreign funding, or their political influence. ${ }^{28}$ Our case study shows how the increasing politicization of these relations pushes the theoretical paradigm away from auxiliary models toward a more political analysis. ${ }^{29}$ This is evident in the Gol's use of antinational rhetoric about Greenpeace's campaign strategy and objectives that led to Greenpeace being labeled as a security threat. In 2014, the government singled out Greenpeace as a lead actor of foreign-funded INGOs acting as a political opposition to the government's development plans. ${ }^{30}$ In 2015 , it canceled GPIN's registration, where the key reason provided was that "acceptance of

\footnotetext{
${ }^{26}$ Beetham [1991] 2013, 20, 33-34.

27 Kilby 2010, 161.

28 Jalali 2008, 2013; Baviskar 2001; Chandhoke 2013.

29 Thrandardottir 2015.

${ }^{30}$ Intelligence Bureau 2014a.
} 
foreign contribution ... has prejudicially affected the public interest ... and has prejudicially affected the economic interest of the State."31

This breakdown in INGO-state relations between Greenpeace and the GoI, and the public debate that ensued, raised a series of questions about whether international donors were buying political influence through locally registered INGOs such as Greenpeace, and how this affected their legitimacy. ${ }^{32}$ A central question arising from this debate was: Who does Greenpeace represent? This is not as straightforward a question as it may seem, mainly because many INGOs do not have members, but also because many do not have the internal structures to validate representation, therefore making the underlying accusation seem moot. ${ }^{33}$ The variety of audiences and legitimacy sources that INGOs rely on can also be confusing in terms of who they are supposedly representing: Is it donors, beneficiaries, or their members? Likewise, when INGOs communicate, be it with ministers, the media, or a local community group, they often take on a representative role, perceived or real..$^{34}$

\section{Whose Agency Counts? The National Context of a Global Campaign}

The background to the problem of who Greenpeace represents in India and its political context is twofold. First, there is India's energy policy to consider as reflecting the needs of a growing power where energy security concerns are an important part of the domestic political debate. Second, there is Greenpeace's Energy Revolution campaign, ongoing since 2005, that targets governments (and industries) on their use of fossil fuels and encourages a more sustainable energy policy. The gap between the policy objectives of GoI's energy policy and Greenpeace’s Energy Revolution campaign reflects the scope and purpose of their respective authority and political agendas. This is particularly evident on the issue of coal and in the divergent scenario assessments made by each actor on its exploitation. It is in this gap that interesting questions arise about the boundary of authorities and representation of global issues in a domestic political context.

As a rising power, India's demand for energy has doubled since 1990 with 25 percent of the population reported to lack basic access to electricity and many areas suffering

\footnotetext{
31 Government of India 2015a.

32 Bahree 2014; Doane 2016; "Foreign-Funded INGOs Stalling Development: IB Report" 2014.

33 Halpin and McLaverty 2010; Rubenstein 2014.

${ }^{34}$ Ellis 2010; Snowdon 2014; Thrandardottir 2017.
} 
repeated blackouts. ${ }^{35}$ A 2016 study on India's energy sources shows "that for every source of energy in the country, the production capacity has not been able to meet the consumption needs." 36 Despite focusing on all energy sources to keep up with demand, increased coal production features heavily in government plans to bridge the supply gap and looks to remain so regardless of party politics. The rationale provided by the GoI for increasing domestic coal production is threefold: 1) to meet the energy demand from a growing population in a country that is considered a rising global power; 2) the need to respond to pressure to modernize the national grid and meet the standards of the global energy market (i.e., turn energy into a tradable product in a standardized market); and 3) to reduce coal imports. ${ }^{37}$ The backdrop to the domestic political debate on energy is therefore structured around electrification, sustained future energy supply, and energy security.

The democratic mandate for addressing these concerns is strong. In the 2014 parliamentary elections in India, the Bharatiya Janata Party (BJP) was elected with an overwhelming majority. One of its campaign promises was to increase "domestic coal exploration and production"38 to bridge the energy supply and demand gap. This was translated into the National Energy Policy, and later the 2015 Coal Bill. ${ }^{39}$ The policy objectives outlined to address the supply gap, including increased exploitation of coal as an energy source, have been on the agenda for some time and are unlikely to change, even with a change of government. ${ }^{40}$ The political will behind coal exploitation is perhaps best indicated in the passing of the 2015 Coal Bill on "coal block" allocation that was passed with a significant majority in parliament. That is not to say that there have been no dissenting political voices. However, within the parliamentary debate, discontent focused on efficiency and transparency of the allocation process rather than coal exploitation per se. ${ }^{41}$ What is interesting is that the voices of political opposition on increased coal production have been identified as coming mainly from the NGO sector. This demonstrates how INGOs have subsumed a political role in domestic policy debates on energy and is central to understanding how GPIN came to be classified as a national

\footnotetext{
35 International Energy Association 2015, 11, 28.

${ }^{36}$ Chakrabarti and Arora 2016, 1493.

${ }^{37}$ Chakrabarti and Arora 2016; Anand and Prasad 2013, 13

38 Bharatiya Janata Party 2014, 34.

39 Parliament of India 2015a.

40 Planning Commission 2013, 8-9.

41 Parliament of India 2015b, 2015c; Government of India 2015b.
} 
security threat.

Energy policy in countries such as India, which have high growth in gross domestic product (GDP), is often a key target for the global environmental lobby. Many INGOs run global campaigns targeting domestic policies that have to do with fossil fuel usage and related environmental issues. In India coal production became a political battleground where international and domestic interests diverged significantly, leading to questions about who INGOs, such as Greenpeace, are representing in their campaigns. Greenpeace International (GPI) started its Energy Revolution campaign in 2005. The main aim of the campaign is to bring about a policy change in the energy sector worldwide by lobbying for a 100 percent renewable energy supply by 2050.42 The campaign targets governments, related industries, and intergovernmental organizations as "powerholders" who embody the "political will" and where GPI's lobbying strategy is to "bring enormous pressure to bear on power-holders" to change that political will to align with the campaign's aim. ${ }^{43}$ The campaign's objectives further reflect its political nature as it calls for legally binding solutions, including ending subsidies and removing distortions in the energy market ${ }^{44}$ - solutions that are traditionally within the realm of the government to decide.

A major output of the Energy Revolution campaign is to publish alternative energy scenarios demonstrating how to replace nonrenewable traditional sources, such as nuclear and fossil, with renewable energy sources. ${ }^{45}$ Its scenario reports are, according to GPI, "widely seen as an alternative view to the IEA's [International Energy Agency] World Energy Outlook." 46 Two things stand out in GPI's fifth scenario report, published in 2015: the first is that GPI projects much lower costs of renewables than official reports do, suggesting that by 2020 renewable energy costs in India and China may be economically viable and possibly cheaper than nonrenewables. ${ }^{47}$ The second is a call for a moratorium on coal as an energy source, whereas the Indian government is looking to increase coal production. That is, regarding investments in coal, GPI's energy campaign

\footnotetext{
42 Greenpeace International, Global Wind Energy Council, and SolarPowerEurope 2015, 8.

${ }^{43}$ Greenpeace UK 2010; Greenpeace International, Global Wind Energy Council, and SolarPowerEurope 2015.

${ }^{44}$ Greenpeace International 2005a, 9.

45 Greenpeace International, Global Wind Energy Council, and SolarPowerEurope 2015, 162.

${ }^{46}$ Greenpeace International, Global Wind Energy Council, and SolarPowerEurope 2015, 4.

${ }^{47}$ Greenpeace International, Global Wind Energy Council, and SolarPowerEurope 2015, 13.
} 
aims to "close down coal power plants and prevent new ones being built" or else "to stop the flow of investment to coal and other dirty fossil fuel projects." 48

These are significant differences when compared with the policy objectives of the GoI, as highlighted in the plans and estimations of India's Ministry of Coal and other governmentrelated bodies. For example, a 2018 report Coal Vision 2030 commissioned by Coal India Limited envisions that "even in the most adverse scenario," demand for coal production is likely to "expand until 2030 and perhaps beyond," possibly trebling in states such as Jharkhand. ${ }^{49}$ Moreover, a report on future trends in coal production from 2013 points out the huge rise in demand for coal in India and adds how this raises security concerns: "For a large economy such as India, maintaining energy self-reliance and security is a strategic need in its own right, even though, there may be an economic argument for keeping open access to imported coal on the margin."50 These predictions have been further supported by other policy-focused research bodies discussing that the "growth of coal is inevitable" if India is to keep up with its energy demand. 51

In addition to the explicitly divergent global and domestic political interests on energy policy and the exploitation of coal as a primary energy source, what also emerges here as an issue is the politicization of the interface between these two authorities and whose interests global authorities like Greenpeace are representing. That is, when campaigning against the government on global policy objectives is GPIN merely acting as putative spokespeople for the environment, and without interests that can be directly attributed to an identifiable set of actors? As far as the existing arguments in the literature go, the answers to such questions remain unsatisfactory where the problem of representation is often sidelined in favor of explanations about epistemic and solidarity-based legitimacy sources of INGOs' power. ${ }^{52}$ Given the lengthy and intense public debate that ensued after the Gol's concerns about Greenpeace were made public in leaked security reports (see below), and if India sets the compass for the Global South in climate negotiations, ${ }^{53}$ these questions become, and indeed became, existential questions for Greenpeace and the future outlook for its legitimacy in the Global South as a leading environmental global

\footnotetext{
${ }^{48}$ Greenpeace International 2016.

${ }^{49}$ Coal India Limited 2018, 11-14.

50 Anand and Prasad 2013, 13.

51 Gowen 2015.

52 Halpin and McLaverty 2010; Rubenstein 2015.

53 Dubash 2011, 2013; Dubash and Florini 2011.
} 
governance actor.

The political dilemma this underscores is how "everything is globalized - that is, everything except politics." 54 Then, how can the divergent policy approaches to a global issue that is deeply embedded in the political narratives of both sides of each authority be resolved? As Greenpeace points out in its documentation of the 2009 and 2014 UN Climate Change Conferences, the conference communiqué was downgraded in both cases "partly as a result of pressure from China and India."55 This is met with the power of GPI to influence domestic policy as a global governance actor. Since it published its Indian segment of the Energy Revolution campaign in 2009, GPIN has been at the forefront of challenging the Indian government's energy policy. ${ }^{56}$ The localization of its argument and campaign agenda is evident in two of the campaigns it has been running in India, one in the Mahan forests regarding deforestation and displacement of locals in relation to coal production, and another on the nuclear energy facility in Tamil Nadu. ${ }^{57}$

In terms of placing effective limits on INGOs' power, this brings the domestic and international dimensions into sharp contrast; that is, who is setting and influencing the global agenda on the environment, how this agenda relates to the domestic political sphere, and who counts as a legitimate actor in this debate. ${ }^{58}$ This is problematic, as we outlined above, because at the international level INGOs have been incorporated as legitimate actors on global issues, which gives them political leverage domestically sometimes up to a point where they are acting as semisovereigns. ${ }^{59}$ Perceptions of INGOs as strategic "cosmopolitan actors" 60 are thus often directly linked to perceptions about them as a political threat and agents of "cosmopolitan politics - a politics that is primarily motivated by a connection beyond the country of each INGO's supporters."61 Our case study demonstrates how this played out for Greenpeace in India. It highlights not only the influence INGOs have on domestic policy, but also how lacking a local mandate in deeply political debates, such as on energy policy, makes them vulnerable to

\footnotetext{
${ }^{54}$ Weiss and Wilkinson 2014, 213.

55 Greenpeace International, Global Wind Energy Council, and SolarPowerEurope 2015, 26; for a wider discussion on India's approach to climate change negotiations, see Dubash 2011, 2013.

${ }^{56}$ Greenpeace International 2009; Sethi 2014.

57 Greenpeace India 2013a, 2013b, n.d.

58 Baviskar 2001, 12.

${ }^{59}$ Shivji 2007, 23-24; Steffek 2013.

${ }^{60}$ Smith and Jenkins 2012.

61 Yanacopulos 2016, 35.
} 
challenges on who they represent when they are perceived to be executing or prioritizing an international agenda at the expense of domestic ones.

\section{The Intelligence Bureau Reports and Politicization of Greenpeace's Agency}

That states should question the legitimacy of INGOs as global actors is not new or surprising. As discussed above, the question of who they represent has been embedded in debates about their role in global governance since their rise as prominent global actors in post-Cold War world politics. ${ }^{62}$ Given how extensive their political reach has become in the past few decades and the increasing politicization of the interface between states and INGOs, a more nuanced theorization of their political agency is needed if we are to accept that placing "effective limits on their power" is necessary. ${ }^{63}$

The view of the GoI on INGOs' influence on domestic policy became evident in two reports by India's Intelligence Bureau (IB), which answers to the Ministry of Home Affairs (MHA), that were leaked to the media in June 2014. It singled out Greenpeace as a key actor running a "coal network" of INGOs seen to be campaigning against the interests of the state. ${ }^{64}$ The aftermath of the leaked reports triggered months of media debates on GPIN's legitimacy, whose interests or agenda it was representing, and how its global agency clashed with domestic policies on energy and coal exploitation. 65 The titles of the reports also reveal this politicization: the first report is titled Concerted Efforts by Select Foreign Funded INGOs to "Take Down" Indian Development Projects, while the second is FCRARegistered Greenpeace Spearheading a Concerted Campaign against India's Energy Expansion Plans. If the reports' assessments and claims provide an insight into how the state views the role of internationally funded and assisted INGOs, and if we take the reports to be expressing genuine concerns, we can say that one of the main problems INGOs have with their agency in the Global South is representation.

The reports make several claims against INGOs in general and Greenpeace in particular. According to the government, INGOs act as the main political opposition to its energy policy, and in so doing they rely on international assistance to operationalize their

\footnotetext{
62 Mathews 1997; Edwards and Hulme 1995; Lipschutz 1992; Charnovitz 1996-1997, 183; Keck and Sikkink 1998.

${ }^{63}$ Lister 2003, 227.

${ }^{64}$ Intelligence Bureau 2014b, 3.

65 Ranjan 2014; Times News Network 2014.
} 
campaigns locally. The GoI estimates that these campaigns are having a significant negative economic impact on India's annual GDP growth. ${ }^{66}$ While the first report takes a general aim at INGOs as a whole, the second report specifically hones in on their activities and the role of Greenpeace. It lists a range of so-called antinational activities from anticoal and antinuclear to campaigns against hydroelectric and mega industrial projects in the eastern state of Odisha. ${ }^{67}$ It further raises specific concerns about the impact of GPIN's anticoal activism in the Singrauli district of Madhya Pradesh, claiming it was instrumental in mobilizing villages around the Mahan forests to form the Mahan Sangharsh Samiti resistance against a proposed coal mine. It singles GPIN out as a key player "growing exponentially in terms of reach, impact, volunteers and media influence" with the intent to "take down" India's coal-fired power plants and coal- mining activity and thereby create obstacles in India's energy plans. ${ }^{68}$ The report further alleges that in so doing GPIN is representing the pro-environmental policies of European governments and that this raises a regulatory conundrum regarding foreign influence on domestic policy. 69

Labeling INGOs as antinational and identifying them as an internationally funded political opposition is significant because in so doing the GoI underscores how their mandate contrasts with the democratic process; for example, the 2015 Coal Bill that was passed in both houses, the Lok Sabha and the Rajya Sabha, of the Indian parliament. Furthermore, these accusations are made in tandem with statements that GPIN's activities are internationally, not domestically, funded. In the period 2011-2013 GPIN's annual reports show that international grants accounted for about 40 percent of its total income, in 2012 this amounted to Indian rupee (INR) 106.5 million out of a total budget of INR 247.4 million (see Table 1). The IB reports conclude by recommending that GPIN should have its FCRA licence revoked. Following suit, the MHA directed the Reserve Bank of India to halt all foreign contributions originating from Greenpeace International and the ClimateWorks Foundation, two principal international contributors to GPIN, until individual clearances were obtained from the MHA for each transaction. ${ }^{70}$

There are three things that emerge from the IB reports that are of consequence for INGOs'

\footnotetext{
66 Intelligence Bureau 2014a.

${ }^{67}$ Intelligence Bureau 2014b, 3.

68 Intelligence Bureau 2014b, 1-3.

${ }^{69}$ Intelligence Bureau 2014b.

70 Business Standard 2014.
} 
global legitimacy. First, they maintain that there is a problematic link between foreign funding and global representation when it comes to INGOs, in which case Greenpeace is at best a representative of foreign private interests. Second, they depict Greenpeace as a potential stooge of European governments' environmental policies seen as inherently biased against India's economic interests, implying GPIN's activities present a risk to national interests that justifies constraining Greenpeace. Third, Greenpeace is seen to lack a legitimate mandate to mobilize local communities against the government on a highly political issue and thus, again, it is seen to pose a national security risk that needs to be constrained. This politicization of INGOs' agency, portraying them as foreign political opposition representing global agendas, shows how charged the interface between global and local authorities has become.

These issues are especially acute for two reasons: first because INGOs' agency is undertheorized in discussions about their political engagement in the Global South where issues of representation tend to be sidestepped. The literature, at best, points to epistemic and solidarity sources of legitimacy but generally fails to address the political aspects of INGOs' global agency. Second, because there are no obvious international processes to mitigate divergent interests between states and INGOs in global governance. This often leaves states with only the option of applying domestic law to place effective limits on INGOs' power, which can lead to draconian or unnecessary clamping down of civil society spaces.

To clarify who Greenpeace represents in India, we offer two frames to explain the limits of its global agency as contextualized in this case study. The first frame is endogenous and uses the internal organization of power in Greenpeace as a measurement for who it can represent, leading to what we call here a narrow agency. The second frame is exogenous, where we use a domestic regulatory shift from a permissive to a restrictive framework to demonstrate how legality functions as a structural barrier to INGOs' global agency. The purpose of the frames is to add empirical knowledge to the existing understandings of INGOs' representation in the literature. In so doing, we aim to contribute to a more nuanced explanation of how Greenpeace's global agency is constructed in India and how its undertheorization is related to structural delegitimation processes of global civil society more generally. 


\section{Endogenous Limits of Greenpeace's Global Agency}

\section{Internal Organization of Power as a Measure of Representation (Frame 1)}

Using internal structures of power as a measure of what type of representation an INGO can generate has been discussed at some length by Darren Halpin. The basic thesis is that if INGOs do not have the capacity to generate democratic structures internally, it is unreasonable to expect them to do so or be measured by its criteria such as representation. Instead, they should be classified as solidarity-based organizations and measured on relevant criteria such as epistemic credibility. ${ }^{71}$ However, there is a mild contradiction here that keeps haunting solidarity-based INGOs such as Greenpeace. That is, despite their internal organization of power falling within the categories of epistemic or solidarity legitimacy, they nonetheless often either make claims that are representative in nature, or are perceived by other powerful actors as representing the interests of some groups or publics when campaigning. ${ }^{72}$ This contradiction is still inadequately solved in the literature and we argue it contributes to delegitimation processes that undermine INGOs' global legitimacy. The unresolved issue of representation stemming from their undertheorized agency is then used against them to undermine their legitimacy as global actors. When Greenpeace announced its strategy to grow its organization in the Global South, this became a structural issue because its ambition to be a global governor of environmental issues was tied in with this unresolved global agency where Greenpeace was making statements about representing people and nature and participating in democratic processes as a global actor without this being grounded or reflected in its internal organization of power.

Greenpeace's expansion into India started in 2001 when it registered a trust that became the Greenpeace India Society under the Tamil Nadu Societies Registration Act 1975 in 2002. Its India mission follows a typical Greenpeace format, focusing on environmental protection such as climate change, sustainable agriculture, preserving the oceans, and preventing nuclear catastrophe. GPIN underwent major organizational restructuring in 2009, based on an audit commissioned by GPI, to initiate a "more strategic and consistent approach towards the four Asian Greenpeace offices - China, Southeast Asia, India and

\footnotetext{
${ }^{71}$ Halpin and McLaverty 2010; Halpin 2009, 2010.

72 Ellis 2010.
} 
Japan'."73 The rationale GPI gave for its global expansion reveals its ambition to become the leading environmental INGO in the region:

This was important both economically and politically. ... Our focus on Asia has lead [sic] to significant investments in our offices in the region, all carefully planned within the three-year plans ... [to] provide strong support and help build a solid foundation to achieve strong climate campaigns and a significant increase of the supporter base there. With this initiative we are also aiming to increase the contribution from our Asian offices to the global organisation, thereby creating a new image for a truly global organisation. ${ }^{74}$

Typically, the term Greenpeace refers to all offices of GPI including itself. GPI is registered as a trust in Amsterdam, and coordinates the work of all Greenpeace offices, including GPIN. The history and governing documents of GPI demonstrate that its organizational structures and power are highly centralized in its executive office. This structure has its own reasons rooted in Greenpeace's organizational history dating back to the 1970 s. ${ }^{75}$ The incorporation and centralization that took place when GPI was established as the key decision-making body of the Greenpeace movement eventually led to the consolidation of power in its executive office. GPI's organizational documents show that it holds significant power over its national offices on key issues, including coordination and approval of campaign agendas, access to the executive meetings of national offices, and power to revoke their license to use the name and logo of Greenpeace. ${ }^{76}$ This centralization of power means that national offices can be highly dependent on the international office for decisions on finance, policy, and campaign strategies.

The result is that national offices are often organized around fund-raising and channeling supporters' solidarity with the Greenpeace cause, rather than around internal processes for voting members that could satisfy a democratic test of representation. ${ }^{77}$ Based on its organizational structure, it can therefore be argued that Greenpeace is not a membership organization since its national offices (albeit sometimes described as members of GPI) only have supporters. That is, the votes that the national offices have at key decisionmaking meetings such as the GPI council meeting are not mandated by members; at best, they represent paid staff of the board of directors of the national offices. This distinction

\footnotetext{
${ }^{73}$ Greenpeace International 2008.

${ }^{74}$ Greenpeace International 2008.

75 Zelko 2004; Weyler 2004.

${ }^{76}$ Greenpeace International 2005b, 6-8, 35-36; 2014a; 2014b.

${ }^{77}$ Halpin and McLaverty 2010.
} 
is important because it leaves the issue of representation unresolved. The strongest analytical version of this frame has the national offices, such as GPIN, representing GPI. The weakest version of this frame has all Greenpeace offices, including GPIN, representing donating supporters. Neither version is adequate for clarifying who GPIN represents if the aim is to place effective limits on its power as posited in the IB reports.

The second component that adds to the complication of who Greenpeace represents is that both GPIN and GPI, despite Greenpeace's solidarity structures, frequently use the backdrop of democracy to frame their rhetoric to imply they are speaking on behalf of what can be understood as a sociopolitical community or constituents:

It speaks for 2.8 million supporters worldwide, and inspires many millions more to take action every day. ... Speaking as we do in defence of our country's environment ... part of a healthy democratic debate ... who wish to voice their concerns about government policies and activities of corporation ... as concerned citizens of India. ${ }^{78}$

One obvious question in response is: So what? Who cares who Greenpeace is claiming to (or actually does) represent? Another question is: What is the theoretical problem with these claims? Do we analyze its power as a normative justice-based claim only, ${ }^{79}$ or do we concede it has an intrinsic empirical or procedural core? ${ }^{80}$ The literature has three main responses to this. One answer, as outlined above, focuses on the democratic context of these claims. That is, under what circumstances is it reasonable to expect INGOs to organize democratically? The argument is that, unless INGOs have credible internal structures to do so, it is unreasonable to raise such expectations. INGOs without democratic structures rely on solidarity support and cannot be expected to live up to legitimacy criteria reserved for a democratic mandate such as representation. ${ }^{81}$ The second answer draws a distinction between representing people and representing causes. The argument is that, where there is no expressed consent, it is possible to understand representation only in terms of epistemic claims, where INGOs "who claim to speak on behalf of those without a voice ... [do so] by appeal to their having knowledge of the objective interests of those groups, often combined with special care for them."

\footnotetext{
78 These quotes are taken from the following documents: Greenpeace International, Global Wind Energy Council, and SolarPowerEurope 2015, 364; Greenpeace India Society 2013, 3; 2014-2015, 5, 9.

79 Rubenstein 2015.

80 Erman 2016, 2018.

${ }^{81}$ Halpin and McLaverty 2010, 69.
} 
However, such claims can "conflict with communities with an already marginalised voice" and, as such, risk overriding the interests of local communities. ${ }^{82} \mathrm{~A}$ third answer is to dismiss the issue of representation as irrelevant and focus on normative concerns about justice, as in the question of whether Oxfam uses its power justly matters more than the question of whether it was elected.83

How, then, can we overcome this impasse? If INGOs want to make bold legitimacy claims and engage in political debates, there is a need for better grounding of their agency in theory to explain their political representativeness. Denying representativeness when an actor is engaging in and making representative claims, or pointing to epistemic legitimacy, is not solving the problem of representation for INGOs but only evading it; ${ }^{84}$ hence, the persistence of states' criticism. ${ }^{85}$ Aside from the academic debate, the INGO sector has worked hard to hedge against accusations about lack of accountability by introducing voluntary frameworks that aim to counter shortcomings in representation. ${ }^{86}$ Yet these schemes remain problematic because they are largely donor or peer based, where legitimacy is conferred by "a closed legitimation circle between global civil society and international organizations," and therefore run the risk of generating nothing more than a "faux-legitimacy." 87 One way to avoid this problem, we argue, is to accept that the internal organization of power in INGOs can be used as a basic measurement of representativeness. This would help us to differentiate between a narrow and a broad agency and thus overcome the impasse in the literature. This distinction could provide a theoretical grounding for building processes that could place not just effective, but also transparent and meaningful, limits on INGOs' power as global governors. A more grounded approach to assessing their global agency could also help with better understanding their initial positions and limits when mitigating political conflicts with other global actors.

In sum, we have shown that the endogenous limits of Greenpeace's power, using GPI's internal organization of power as a measurement of representation, lead to a narrow interpretation of their global agency as we can only safely infer that GPIN represents GPI.

\footnotetext{
82 O’Neill 2001, 496-497.

83 Rubenstein 2014, 2015.

${ }^{84}$ Ellis 2010.

85 Kamminga 2007.

86 Brown 2008; Accountable Now 2019.

87 Anderson 2010, 884.
} 
This has consequences for how we hold them to account as global actors. Thus, we turn to the next section and an exogenous frame to provide analytical insight into how domestic regulation functions as a structural barrier to INGOs' global agency.

\section{FCRA as a Structural Barrier to INGOs' Legitimacy (Frame 2)}

If the hope was that the GoI would embrace INGOs in the same fashion that existing global powers have (e.g., the United States and the United Kingdom), the FCRA regulatory shift is disappointing. Rather, the fact that the FCRA aims to push back against INGOs as global actors campaigning on issues that are embedded in domestic politics highlights how representation has become a global regulatory problem for leading INGOs (although regulating international activities of INGOs in domestic courts is not an entirely new problem ${ }^{88}$ ). It has pushed the representation question into the analytical dimension of procedural politics and undermines the cosmopolitan side of INGOs as representing universal values. Even if this development is undesirable, it was perhaps foreseeable. Since the mid-1980s multilateral organizations have been championing the growth of INGOs globally. ${ }^{89}$ At the same time, during this period there has been limited discussion about creating international processes to regulate their growing power as global actors. ${ }^{90}$ It is with the rise of India and China as new powers that this has surfaced as a global governance problem. One observable trend of the pushback is states implementing more stringent INGO regulation, ${ }^{91}$ a trend that has become more pronounced as leading INGOs are restructuring to grow their activities and membership at the national level in the Global South. ${ }^{92}$

In India this is evident in the shift from a more permissive INGO regulatory framework, SRA, to a more restrictive one, FCRA. India regulates INGOs at both the federal and state levels. There are six acts of parliament that directly affect INGOs. These are the Societies Registration Act 1860, the Foreign Contribution (Regulation) Act 2010, the Indian Companies Act 2013, the Bombay Public Trusts Act 1950, the Indian Trusts Act 1882, and the Income Tax Act 1961. The regulatory agencies at the state level include the Charity Commissioner (for Trusts), the Registrar of Societies (referred to in some states by

\footnotetext{
${ }^{88}$ McGovern v. Attorney-General.

${ }^{89}$ Cernea 1988; UN 2004.

90 Avant, Finnemore, and Sell 2010; Macdonald 2008.

91 Rutzen 2015; Christensen and Weinstein 2013; Moore and Rutzen 2011.

92 Hauger, Daniels, and Saalman 2014, 256; BOND 2014, 19.
} 
different titles, including the Registrar of Joint Stock Companies), and the Registrar of Companies (for Section 25 companies). At the federal level, international donations are regulated centrally through the Income Tax Department of the Ministry of Finance, and the FCRA under the MHA. In principle INGOs can register as either societies, public charitable trusts, or as private nonprofit companies. However, the most preferred legal form of INGO in India is to register as a society. This preference has two reasons: one is the higher cost and taxes under alternative registrations such as the Section 25 company registration, and the other is that the Charities Commissioner has less power to intervene in the affairs of a society compared to other registrations such as a trust. Over time, the SRA has therefore become the most relevant legal and regulatory format for INGOs focusing on charitable activities. ${ }^{93}$

Although the SRA has hitherto been the most significant legal instrument for regulating INGOs, the FCRA has become increasingly important in regulating foreign donations to INGOs since 2010. The FCRA dates back to 1976. Although the FCRA 1976 should be read and understood in the political context of the time, ${ }^{94}$ the spirit and purpose of the 2010 law remains the same; that is, to regulate undue influence on electoral politics within India so as to ensure that a "foreign contribution" is not used to fund "activities detrimental to the national interest." 95 The act stipulates that organizations or individuals subject to the act that wish to accept foreign funds cannot do so without "prior permission" from the GoI. ${ }^{96}$ What has changed in the FCRA 2010 version is twofold. First, it includes much more detail on procedure, including registration and monitoring of accounts of those subject to the act. Second, the application of the FCRA 2010 to regulate INGOs reflects the changes global governance has brought to domestic politics in India. It is this second point that is relevant for our argument because, although the purpose of the law has not changed, its use reflects a new political reality - one that is concerned with regulating the influence of global actors pushing for global governance regimes in the Global South.

This shift in the target audience can be interpreted as an escalation of tensions between

\footnotetext{
${ }^{93}$ For more details on the legal environment for NGOs in India, see International Center for Not-for-Profit Law 2019.

94 Jalali 2008, 172; Sen 1999, 343; Bhat 2013.

95 Government of India 1976, Preamble, Chapter 2; 2010, Preamble, Chapter 2, Section 2(h), Section 3(1).

96 Government of India 1976, Chapter 2, Section 5; Government of India 2010, Chapter 2, Sections 5-9.

"Organization" or "individuals" to be understood as defined in Chapter 1, Section 1 of both acts.
} 
INGOs and the state as is evident in the Parliamentary Standing Committee on Home Affairs's report on the Foreign Contribution (Regulation) Bill 2006. The report notes the "ever increasing influence of voluntary organizations" and the resulting "quantum jump in the amount of foreign contribution being received" as key reasons, along with internal security, for replacing the FCRA $1976 .{ }^{97}$ The aim is to manage the increased interaction and volume of transactions by strengthening the monitoring of INGOs and increasing the transparency of the process. Part of the controversy it caused is a perception that the FCRA 2010 imposes a cumbersome bureaucracy on INGOs around reporting of the receipt and utilization of foreign funding. This includes detailed regulation of the amount of money received, the source of the money, and the method of receipt as well as the purpose and use of the donation. ${ }^{98}$ The objections raised to the FCRA 2010, including the 2011 Foreign Contribution Rules and its 2012 and 2015 Amendment Rules, highlight the act's wide scope and lack of definitional clarity. The worries raised are that these will function as a significant "barrier to resources" for INGOs, therefore prohibiting rather than enabling their engagement. ${ }^{99}$

Thus, Greenpeace's attempt at localizing its Energy Revolution campaign in India and establishing its authority as a regional gatekeeper was met with strong resistance at the national political level where the GoI probed the legitimate authority of GPIN insisting on detailed information about its internal organization of power, governance, and funding. Greenpeace India was badly affected by these changes and avoided complete closure only through a High Court order after having had its FCRA licence suspended and then canceled (see Table 2 for a timeline). The Greenpeace India case study shows how the FCRA 2010 is an attempt to draw a clearer national boundary for global authority (on what the GoI considers to be illegitimate foreign influence on local politics by INGOs), because the changes introduced can be interpreted as a more restrictive regulatory framework, especially when compared to the more permissive SRA regulation. Although it provides some clarity on how we can place effective limits on INGOs' power, what it also highlights is the complexity and complications of INGOs' cosmopolitan outlook, including the intricate web of transactions between the national and international

\footnotetext{
97 Committee on Home Affairs 2008, Rajya Sabha 134, Section 2.1, p. 7.

98 These stipulations are detailed in the FCRA 2010 and its amendments; see, for example, Government of India 2010, Chapter 2, Sections 5-8, pp. 6-8; 2012, Section 2; 2015c, Rule 13(b), Rule 16, Rule 17A.

99 The International Center for Not-For-Profit-Law 2019; Committee on Home Affairs 2008.
} 
legitimacy sources they draw on. It further shows how INGOs, despite having some protection in international treaties, remain heavily dependent on domestic law for mitigating problems with state actors. ${ }^{100}$

In sum, INGO legitimacy is increasingly being framed as a political problem in need of a legal response, whether in terms of how to apply regulation to INGOs that are considered political or what constitutes an acceptable level of "political activity." 101 As scholars point out, this trend is recurring across continents and reflects harsher attitudes from states and a tougher regulatory reality for INGOs, which may pose a serious challenge to the underlying structure of global civil society. ${ }^{102}$ In some respects, this development and the situation that INGOs are now in can be understood as a failure of international society to adequately protect civil society. Apart from the UN special rapporteur on civil society submitting a legal information note to the GoI, there is little to suggest that new safeguards are being thought of, with a mixture of domestic law and self-regulatory frameworks as the way forward for INGO regulation. ${ }^{103}$ Based on our case study, we maintain that this is wholly inadequate as a way forward for the sector, from both states' and INGOs' perspectives, as legitimate concerns about representation and foreign funding are reproducing structural delegitimation processes that undermine the foundation of global civil society.

\section{Conclusion}

In this article, we sought to clarify the issue of representation as it affected Greenpeace in India. Our case study contributes to a discussion in the global governance literature about boundaries between global and local authorities and the politicization of the interface between them. The article offered two analytical frames to explore how nonstate global actors, such as INGOs, struggle to maintain their legitimacy in the Global South. In so doing, we contributed two propositions to inform the theoretical debate. The first is that Greenpeace's representativeness in India is best understood in terms of narrow agency. The second is that establishing functional boundaries of INGOs' power in terms of legality

\footnotetext{
100 Kiai 2013; Thrandardottir and Keating 2018.

101 Moore and Rutzen 2011; Rutzen 2015.

102 Yanacopulos 2016; Rutzen 2015.

${ }^{103}$ Kiai 2016; UN General Assembly 2016.
} 
remains an elusive task without better protection in international law. Most problems that INGOs face do not make the headlines and most INGOs do not have the resources to challenge governments in the courts. A process is needed, then, whereby political concerns can be addressed and mitigated without severe costs to INGOs or, indeed, to states. Even if international society has started, however inadequately, to address the organizational and financial gaps in the governance of legitimate political authority at the global level, it seems the solution to the dilemma of global representation is still a long way off. 


\section{Bibliography}

Accountable Now. “Resources.” 2019. https://accountablenow.org/resources/.

Anand, M.R., and D.N. Prasad. "Recent Trends in Production and Import of Coal in India." Ministry of Coal. Occasional Working Paper Series 1 (13) (2013), 1-18.

https://coal.nic.in/sites/upload_files/coal/files/coalupload/wp101014.pdf.

Anderson, Kenneth. "Accountability as Legitimacy: Global Governance, Global Civil Society and the United Nations." Brooklyn Journal of International Law 36 (3) (2010), 841-890.

Avant, Deborah D., Martha Finnemore, and Susan K. Sell. Who Governs the Globe? (Cambridge: Cambridge University Press, 2010).

Bahree, Megha. "Modi Government's Message to INGOs in India: Big Brother Is Watching You." Forbes, 16 June 2014. https://www.forbes.com/sites/meghabahree/2014/06/16/modigovernments-message-to-ngos-in-india-big-brother-is-watching-you/\#5a3c08ab5505.

Baviskar, Baburao Shravan. "NGOs and Civil Society in India." Sociological Bulletin 50 (1) (2001), 3-15. http://www.jstor.org/stable/23620147.

Beetham, David. The Legitimation of Power (Basingstoke: Palgrave Macmillan, [1991] 2013).

Bharatiya Janata Party. “Ek Bharat Shreshtha Bharat” Election Manifesto. 2014.

http://www.bjp.org/images/pdf_2014/full_manifesto_english_07.04.2014.pdf.

Bhat, P. Ishwara. "Balancing Transnational Charity with Democratic Order, Security, Social Harmony and Accountability: A Critical Appraisal of the Foreign Contribution (Regulation) Act, 2010." Journal of Indian Law and Society 4 (2) (2013), 155-182.

BOND (British Overseas NGOs for Development). Fast Forward: The Changing Role of UK-Based INGOs. London, 1 July 2014. https://www.bond.org.uk/resources/fast-forward.

Brown, L. David. Creating Credibility: Legitimacy and Accountability for Transnational Civil Society (Sterling, VA: Kumarian Press, 2008).

Business Standard. “Govt Puts Greenpeace in Tight Spot.” World Wildlife Fund India and Environmental Information System, 20 June 2014.

http://wwfenvis.nic.in/ViewGeneralLatestNews.aspx?Id=3806\&Year=2014.

Cernea, Michale M. “Nongovernmental Organizations and Local Development." World Bank Discussion Papers No. 40 (Washington, DC: World Bank, 1988).

Chakrabarti, Anindita, and Ravinder Kumar Arora. "India's Energy Security: Critical Considerations." Global Business Review 17 (6) (2016), 1480-1496.

https://doi.org/10.1177/0972150916660443.

Chandhoke, Neera. "Realising Justice." Third World Quarterly 34 (2) (2013), 305-320. DOI 10.1080/01436597.2013.775787.

Charnovitz, Steve. "Two Centuries of Participation: NGOs and International Governance." Michigan Journal of International Law 18 (2) (1996-1997), 183-286.

Christensen, Darin, and Jeremy M. Weinstein. "Defunding Dissent: Restrictions on Aid to NGOs." Journal of Democracy 24 (2) (2013), 77-91. DOI 10.1353/jod.2013.0026.

Coal India Limited. “Coal Vision 2030: Stakeholders' Consultation.” 2018. 
https://www.coalindia.in/DesktopModules/DocumentList/documents/Coal_Vision_2030_docu ment_for_Coal_Sector_Stakeholders_Consultation_27012018.pdf.

Coen, David, and Tom Pegram. "Towards a Third Generation of Global Governance Scholarship." Global Policy 9 (1) (2018), 107-113. DOI 10.1111/1758-5899.12527.

Collingwood, Vivien. "Non-governmental Organisations, Power and Legitimacy in International Society." Review of International Studies 32 (3) (2006), 439-454. DOI $10.1017 /$ S0260210506007108.

Committee on Home Affairs. Department-Related Parliamentary Standing Committee on Home Affairs One Hundred and Thirty Fourth Report on the Foreign Contribution (Regulation) Bill, 2006 (21 October 2008), Rajya Sabha 134, Section 2.1, p. 7.

https://www.prsindia.org/uploads/media/1168509118/scr1224826398_The_Foreign_Contrib ution_Regulation_Bill_2006.pdf.

Corry, Dan, and Gerry Stoker. “The 'Shared Society' Needs a Strong Civil Society.” New Philanthropy Capital, 13 April 2017. https://www.thinknpc.org/publications/the-sharedsociety-needs-a-strong-civil-society/.

Dellmuth, Lisa Maria, and Jonas Tallberg. "Advocacy Strategies in Global Governance: Inside versus Outside Lobbying." Political Studies 65 (3) (2017), 705-723. DOI 10.1177/0032321716684356.

Doane, Deborah. "The Indian Government Has Shut the Door on INGOs." The Guardian, 7 September 2016. https://www.theguardian.com/global-development-professionalsnetwork/2016/sep/07/the-indian-government-has-shut-the-door-on-ngos.

Dubash, Navroz Kersi, "From Norm Taker to Norm Maker? Indian Energy Governance in Global Context." Global Policy 2 (1) (2011), 66-79. DOI 10.1111/j.1758-5899.2011.00123.x

Dubash, Navroz Kersi. "'Of Maps and Compasses: India in Multilateral Climate Negotiations." In Shaping the Emerging World: India and the Multilateral Order, eds. Waheguru Pal Singh Sidhu, Pratap Bhanu Mehta, and Bruce Jones (Washington, DC: Brookings Institution Press, 2013), 261-279.

Dubash, Navroz Kersi, and Ann Florini. "Mapping Global Energy Governance." Global Policy 2 (1) (2011), 6-18. DOI 10.1111/j.1758-5899.2011.00119.x.

Edwards, Michael, and David Hulme, eds. Non-governmental Organisations: Performance and Accountability: Beyond the Magic Bullet (London: Earthscan, 1995).

Ellis, Peter. "The Ethics of Taking Sides." In Ethical Questions and International NGOs: An Exchange between Philosophers and NGOs, eds. Keith Horton and Chris Roche (London: Springer, 2010), 65-85.

Erman, Eva. "Global Political Legitimacy beyond Justice and Democracy?" International Theory 8 (1) (2016), 29-62

Erman, Eva. "The Political Legitimacy of Global Governance and the Proper Role of Civil Society Actors." Res Publica 24 (1) (2018), 133-155.

"Foreign-Funded INGOs Stalling Development: IB Report." The Times of India, 12 June 2014. http://timesofindia.indiatimes.com/india/Foreign-funded-INGOs-stalling-development-IBreport/articleshow/36411169.cms.

Fukuyama, Francis. Political Order and Political Decay: From the Industrial Revolution to the 
Globalization of Democracy (London: Profile Books, 2015).

Government of India. The Foreign Contribution (Regulation) Act 1976 (No. 49 of 1976), Preamble, Chapter 2.

https://www.prsindia.org/uploads/media/1168509118/bill87_2007032287_FCRA_1976.pdf.

Government of India. The Foreign Contribution (Regulation) Act 2010 (No. 42 of 2010), Preamble, Chapter 2, Section 2(h), Section 3(1). https://fcraonline.nic.in/home/PDF_Doc/FCRegulationAct-2010-C.pdf.

Government of India. Foreign Contribution (Regulation) Amendment Rules 2012. The Gazette of India, New Delhi, Notification (12 April 2012), Section 2.

https://indiacode.nic.in/ViewFileUploaded?path=AC_CEN_5_24_00024_201042_151780732780

$2 /$ rulesindividualfile $/ \&$ file=Foreign+Contribution $+\% 28$ Regulation $\% 29+$ Amendment+Rules +20 12.pdf.

Government of India. Order. Ministry of Home Affairs Foreigners Division (FCRA Wing). National Informatics Centre. 2 September 2015a.

https://fcraonline.nic.in/home/PDF_Doc/Greenpaece\%20India\%20Society2_040915.PDF.

Government of India. The Coal Mines (Special Provisions) Act, 2015 (No. 19 of 2015). 2015b. http://164.100.47.193/BillsPDFFiles/Notification/2015-19-gaz.pdf.

Government of India. Foreign Contribution (Regulation) Amendment Rules 2015. The Gazette of India, New Delhi, Notification (14 December 2015c), Rule 13(b), Rule 16, Rule 17A.

https://fcraonline.nic.in/home/PDF_Doc/doc00600120151214130739.pdf.

Gowen, Annie. “On Obama's India Visit, Climate-Change Deal Unlikely as Modi Boosts Coal Production." The Washington Post, 24 January 2015.

https://www.washingtonpost.com/world/asia_pacific/heres-why-obama-wont-get-a-climatedeal-with-india-this-trip/2015/01/24/77fb95cc-9ccf-11e4-86a3-1b56f64925f6_story.html.

Greenpeace India. "Save Mahan, Our Rights, Our Forests.” Greenpeace International, 2013a. http://www.greenpeace.org/india/en/What-We-Do/Quit-Coal/save-mahan/.

Greenpeace India. "MSS Formed in Singrauli to Protect Forests \& Rights of Forest Communities." Greenpeace International, 27 March 2013b. https://www.greenpeace.org/archiveindia/en/news/Feature-Stories/Mahan-Sangharsh-Samiti-formed-in-Singrauli-to-protectforests--rights-of-forest-dependent-communities--/.

Greenpeace India. "Jaitapur Nuclear Power Plant Protest." n.d.

https://www.greenpeacex.in/petitions/jaitapur-nuclear-power-plant-protest.

Greenpeace India Society. “Annual Report” (Greenpeace India Society, Bangalore, 2013).

Greenpeace India Society. “Annual Report” (Greenpeace India Society, Bangalore, 2014-2015).

Greenpeace International. "Energy Revolution: A Sustainable Pathway to a Clean Energy Future for Europe." 2005a. http://www.greenpeace.org/archive-

international/Global/international/planet-2/report/2005/10/energy-revolution-asustainab.pdf.

Greenpeace International. "Greenpeace Governance Handbook" (Greenpeace International, Amsterdam, 2005b).

Greenpeace International. "Annual Report.” 2008.

http://www.greenpeace.org/international/Global/international/planet- 
2/report/2009/11/international-annualreport-2008.pdf.

Greenpeace International. "India Can Vote for an Energy [R]Evolution.” 2009.

http://www.energyblueprint.info/795.0.html.

Greenpeace International. "Stichting Greenpeace Council Articles of Association: As approved at AGM 2014” (Greenpeace International, Amsterdam, 2014a).

Greenpeace International. "Stichting Greenpeace Council Rules of Procedure: As Approved at AGM 2014.” (Greenpeace International, Amsterdam, 2014b).

Greenpeace International. “Why We Must Quit Coal.” 2016.

http://www.greenpeace.org/international/en/campaigns/climate-change/coal/.

Greenpeace International, Global Wind Energy Council, and SolarPowerEurope. "Energy Revolution: A Sustainable World Energy Outlook 2015." Greenpeace International, September 2015. https://www.greenpeace.org/archive-international/en/campaigns/climatechange/energyrevolution/\#tab $=0$.

Greenpeace UK. "How We Make Change Happen." 2010.

http://www.greenpeace.org.uk/about/how-we-make-change-happen.

Hale, Thomas, and David Held. "Breaking the Cycle of Gridlock." Global Policy 9 (1) (2018), 129137. DOI 10.1111/1758-5899.12524.

Hale, Thomas, David Held, and Kevin Young. Gridlock: Why Global Cooperation Is Failing when We Need It Most (Cambridge, United Kingdom: Polity Press, 2013).

Halpin, Darren. "NGOs and Democratisation: Assessing Variation in the Internal Democratic Practices of NGOs." In NGOs in Contemporary Britain: Non-state Actors in Society and Politics since 1945, eds. Nick Crowson, Matthew Hilton, and James Mckay (Basingstoke: Palgrave Macmillan, 2009), 261-280.

Halpin, Darren. Groups, Representation and Democracy: Between Promise and Practice (Manchester: Manchester University Press, 2010).

Halpin, Darren, and Peter McLaverty. "Legitimating INGO Advocacy: The Case of Internal Democracies." In Evaluating Transnational INGOs: Legitimacy, Accountability, Representation, eds. Jens Steffek and Kristina Hahn (Basingstoke: Palgrave Macmillan, 2010), 55-73.

Hauger, Scott J., Michael Daniels, and Lora Saalman. "Environmental Security and Governance at the Water-Energy Nexus: Greenpeace in China and India." Journal of Asian Security and International Affairs 1 (3) (2014), 235-261.

Hofferberth, Matthias. "Get Your Act(ors) Together! Theorizing Agency in Global Governance." International Studies Review (2018), 21 (4), 127-145. DOI 10.1093/isr/viy018.

Intelligence Bureau. Concerted Efforts by Select Foreign Funded INGOs to "Take Down" Indian Development Projects. 3 June 2014a. https://www.scribd.com/doc/229511459/IB-ReportINGOs-June-2014.

Intelligence Bureau. FCRA-Registered Greenpeace Spearheading a Concerted Campaign against India's Energy Expansion Plans. 9 June 2014b.

https://www.documentcloud.org/documents/1201267-greenpeace-ib-report.html.

International Center for Not-for-Profit Law. "Closing Civic Space: Impact on Development and Humanitarian CSOs." Global Trends in NGO Law 7 (3) (2016), 1-19. 
International Center for Not-for-Profit Law. "Restrictions on Protest in the United States." Global Trends in NGO Law 9 (1) (2018), 1-18.

International Center for Not-for-Profit Law. "Civic Freedom Monitor: India.” 10 September 2018. http://www.icnl.org/research/monitor/india.html.

International Energy Association. "India Energy Outlook: World Energy Outlook Special Report." 2015.

https://www.iea.org/publications/freepublications/publication/IndiaEnergyOutlook_WEO201 5.pdf.

Jalali, Rita. "International Funding of INGOs in India: Bringing the State Back In." Voluntas: International Journal of Voluntary and Nonprofit Organizations 19 (2) (2008), 161-188. DOI 10.1007/s11266-008-9059-7.

Jalali, Rita. "Financing Empowerment? How Foreign Aid to Southern NGOs and Social Movements Undermines GrassRoots Mobilization." Sociology Compass 7 (1) (2013), 55-73. DOI $10.1111 / \operatorname{soc} 4.12007$.

Kamminga, Menno T. "What Makes an NGO 'Legitimate' in the Eyes of States?" In NGO Involvement in International Governance and Policy: Sources of Legitimacy, ed. Anton Vedder (Leiden: Martinus Nijhoff, 2007), 175-195.

Keck, Margaret E., and Kathryn Sikkink. Activists beyond Borders: Advocacy Networks in International Politics (Ithaca: Cornell University Press, 1998).

Kiai, Maina. Report of the Special Rapporteur on the Rights to Freedom of Peaceful Assembly and of Association. UN General Assembly (2013). http://dag.un.org/handle/11176/304244.

Kiai, Maina. Analysis on International Law, Standards and Principles Applicable to the Foreign Contributions Regulation Act 2010 and Foreign Contributions Regulation Rules 2011 (New York: UN, 2016).

Kilby, Patrick . INGOs in India: The Challenges of Women's Empowerment and Accountability (London: Routledge, 2010).

Lake, David A. "Rightful Rules: Authority, Order, and the Foundations of Global Governance." International Studies Quarterly 54 (3) (2010), 587-613. DOI 10.1111/j.1468-2478.2010.00601.x.

Lake, David A., and Mathew D. McCubbins. "The Logic of Delegation to International Organizations." In Delegation and Agency in International Organizations, eds. Daniel L. Nielson, Darren G. Hawkins, David A. Lake, and Michael J. Tierney (Cambridge: Cambridge University Press, 2006), 341-368.

Lang, Sabine. NGOs, Civil Society, and the Public Sphere (Cambridge: Cambridge University Press, 2012).

Lindblom, Anna-Karin. Non-governmental Organisations in International Law (Cambridge: Cambridge University Press, 2005).

Lipschutz, Ronnie D. "Reconstructing World Politics: The Emergence of Global Civil Society." Millennium 21 (3) (1992), 389-420. DOI 10.1177/03058298920210031001.

Lister, Sarah. "NGO Legitimacy: Technical Issue or Social Construct?" Critique of Anthropology 23 (2) (2003), 175-192. DOI 10.1177/0308275X03023002004.

Macdonald, Terry. "What's so Special about States? Liberal Legitimacy in a Globalising World." 
Political Studies 56 (2008), 544-565. DOI 10.1111/j.1467-9248.2008.00750.x.

Mathews, Jessica Tuchman. "Power Shift." Foreign Affairs 76 (1) (1997), 50-67.

McGovern v. Attorney-General [1982] 1 Ch 321, [1981] 3 All ER 493.

Moore, David, and Douglas Rutzen. "Legal Framework for Global Philanthropy: Barriers and Opportunities." International Journal of Not-for-Profit Law 13 (1-2) (2011), 5-41.

O’Neill, John. "Representing People, Representing Nature, Representing the World." Environment and Planning C 19 (4) (2001), 483-500.

Parliament of India. The Coal Mines (Special Provisions) Bill 2015 [Lok Sabha], Bill 19 (As Introduced in Lok Sabha). 2015a.

https://www.prsindia.org/uploads/media/Coal\%20Mines/Coal\%20Mines\%20Bill,\%202015.p df.

Parliament of India. The Coal Mines (Special Provisions) Bill [Lok Sabha], Bill 19-C. 2015b. http://164.100.47.194/Loksabha/Legislation/billspassed.aspx.

Parliament of India. Further Discussion on the Motion to Consider Statutory Resolution Regarding Disapproval of Coal Mines (Special Provisions) Second Ordinance, 2014 (No. 7 of 2014) and the Coal Mines (Special Provisions) Bill, 2015 (Statutory Resolution Withdrawn and Government Bill-Passed). 4 March 2015c. Sixteenth Lok Sabha, 2015.

http://164.100.47.194/Loksabha/Debates/Result16.aspx?dbsl=3139.

Peruzzotti, Enrique. "Civil Society, Representation and Accountability: Restarting Current Debates on the Representativeness and Accountability of Civic Associations." In NGO

Accountability: Politics, Principles and Innovations, eds. Lisa Jordan and Peter van Tuijl (London: Earthscan, 2006), 43-58.

Planning Commission, Government of India. Twelfth Five-Year Plan (2012-17): Faster, More Inclusive and Sustainable Growth: Volume 1 (New Dehli: Sage Publications India Pvt Ltd, 2013). http://planningcommission.nic.in/plans/planrel/fiveyr/welcome.html.

Ranjan, Amitav. "Foreign-Aided NGOs Are Actively Stalling Development, IB Tells PMO in a Report." The Indian Express, 7 June 2014. Accessed 6 January 2016 from

http://indianexpress.com/article/india/india-others/ib-report-to-pmo-greenpeace-is-a-threatto-national-economic-security/\#sthash.oxhng09p.jkE3BCCm.dpuf

Reimann, Kim D. "A View from the Top: International Politics, Norms and the Worldwide Growth of NGOs." International Studies Quarterly 50 (1) (2006), 45-67.

http://www.jstor.org/stable/3693551.

Rubenstein, Jennifer C. "The Misuse of Power, Not Bad Representation: Why It Is Beside the Point That No One Elected Oxfam." Journal of Political Philosophy 22 (2) (2014), 204-230. DOI 10.1111/jopp.12020.

Rubenstein, Jennifer C. Between Samaritans and States: The Political Ethics of Humanitarian INGOs (Oxford: Oxford University Press, 2015).

Rutzen, Douglas. "Aid Barriers and the Rise of Philanthropic Protectionism." International Journal of Not-for-Profit Law 17 (1) (2015), 5-44.

Sen, Siddhartha. "Some Aspects of State-NGO Relationships in India in the Post-Independence Era." Development and Change 30 (2) (1999), 327-355. DOI 10.1111/1467-7660.00120. 
Sethi, Nitin. "India Has Been Speaking from Equity Perspective, We See It Differently: Samit Aich.” Business Standard, 27 June 2014. Accessed 12 February 2019 from:

https://www.business-standard.com/article/current-affairs/india-has-been-speaking-fromequity-perspective-we-see-it-differently-samit-aich-114062700176_1.html

Shivji, Issa Gulamhussein. Silences in NGO Discourse: The Role and Future of INGOs in Africa (Nairobi: Fahamu, 2007).

Baillie Smith, Matt, and Katy Jenkins. "Existing at the Interface: Indian NGO Activists as Strategic Cosmopolitans.” Antipode 44 (3) (2012), 640-662. DOI 10.1111/j.1467-8330.2011.00888.x.

Snowdon, Christopher. "The Sock Doctrine: What Can Be Done about State-Funded Political Activism?" Discussion Paper No. 53 (London: The Institute of Economic Affairs, 2014).

Steffek, Jens. "Explaining Cooperation between IGOs and NGOs - Push Factors, Pull Factors, and the Policy Cycle." Review of International Studies 39 (4) (2013), 993-1013. DOI $10.1017 /$ S0260210512000393.

Stroup, Sarah S., and Wendy H. Wong. The Authority Trap: Strategic Choices of International NGOs (London: Cornell University Press, 2017).

Thrandardottir, Erla. "NGO Legitimacy: Four Models." Representation: Journal of Representative Democracy 51 (1) (2015), 107-123. DOI 10.1080/00344893.2015.1023102.

Thrandardottir, Erla. “NGO Audiences: A Beethamite Analysis.” Working Papers on Transnational Politics, CUTP 013 (London: City, University of London, 2017). http://openaccess.city.ac.uk/id/eprint/16655.

Thrandardottir, Erla, and Vincent Charles Keating. "Bridging the Legitimacy Gap: A Proposal for the International Legal Recognition of INGOs." International Politics 55 (2) (2018), 207-220. DOI 10.1057/s41311-017-0098-9.

Times News Network. "Foreign-Funded INGOs Stalling Development: IB Report." The Times of India, 12 June 2014. Accessed on 5 June 2017 from:

http://timesofindia.indiatimes.com/india/Foreign-funded-INGOs-stalling-development-IBreport/articleshow/36411169.cms..

UN. We the Peoples: Civil Society, the United Nations and Global Governance: Report of the Panel of Eminent Persons on United Nations-Civil Society Relations. UN Doc. A/58/817. (New York: UN, 11 June 2004).

UN. Satellite Account on Nonprofit and Related Institutions and Volunteer Work (New York: UN, 2018). https://unstats.un.org/unsd/nationalaccount/docs/UN_TSE_HB_FNL_web.pdf.

UN General Assembly. Resolution Adopted by the Human Rights Council on 1 July 2016. Human Rights Council. UN Doc. A/HRC/RES/32/32 (18 July 2016).

Vedder, Anton, ed. NGO Involvement in International Governance and Policy: Sources of Legitimacy (Leiden: Martinus Nijhoff, 2007).

Walton, Oliver Edward, Thomas Davies, Erla Thrandardottir, and Vincent Charles Keating. "Understanding Contemporary Challenges to INGO Legitimacy: Integrating Top-down and Bottom-up Perspectives." Voluntas: International Journal of Voluntary and Nonprofit Organizations 27 (6) (2016), 2764-2786. DOI 10.1007/s11266-016-9768-2.

Weiss, Thomas George, and Rorden Wilkinson. "Rethinking Global Governance? Complexity, Authority, Power, Change." International Studies Quarterly 58 (1) (2014), 207-215. DOI 
10.1111/isqu.12082.

Weyler, R. Greenpeace an Insider's Account: How a Group of Journalists, Ecologists, and Visionaries Changed the World. (London: Rodale, 2004).

Yanacopulos, Helen. International NGO Engagement, Advocacy, Activism: The Faces and Spaces of Change (Basingstoke: Palgrave Macmillan, 2016).

Zelko, Frank. "'Make It a Green Peace': The History of an International Environmental Organisation." German Historical Institute Washington DC Bulletin (34) (2004), 127-135.

Zürn, Michael. "From Constitutional Rule to Loosely Coupled Spheres of Liquid Authority: A Reflexive Approach." International Theory 9 (2) (2017), 261-285. DOI $10.1017 /$ S1752971916000270.

Zürn, Michael. “Contested Global Governance.” Global Policy 9 (1) (2018), 138-145. DOI 10.1111/1758-5899.12521. 
Table 1: Domestic and Foreign Donations to Greenpeace India 2011-2015

\begin{tabular}{|l|l|l|l|l|}
\hline $\begin{array}{l}\text { Source of } \\
\text { Income } \\
\text { (INR } \\
\text { millions) }\end{array}$ & 2011 & 2012 & 2013 & $2014-15$ \\
\hline Domestic & $110.88(57.3 \%)$ & $133.63(54.0 \%)$ & $192.40(57.5 \%)$ & $179.96(63.4 \%)$ \\
\hline Foreign & $77.01(39.8 \%)$ & $106.54(43.1 \%)$ & $131.88(39.4 \%)$ & $96.19(33.9 \%)$ \\
\hline Interest & $5.19(2.7 \%)$ & $7.02(2.8 \%)$ & $10.14(3.0 \%)$ & $7.55(2.7 \%)$ \\
\hline Other & $0.38(0.2 \%)$ & $0.18(0.1 \%)$ & $0.26(0.1 \%)$ & $0.00(0.0 \%)$ \\
\hline Total & 193.46 & 247.36 & 334.67 & 283.70 \\
\hline
\end{tabular}

Source: Compiled from Greenpeace India Annual Reports 2011-2015.

Table 2: Chronological Table of Events 2013-2015

\begin{tabular}{|l|l|}
\hline DATE & EVENT \\
\hline May 2013 & $\begin{array}{l}\text { India's Twelfth Five Year Plan (2012-2017) published outlining plans } \\
\text { for increase in domestic coal production. It makes clear that coal is a } \\
\text { significant source of primary energy that is to be exploited to support } \\
\text { domestic energy consumption. }\end{array}$ \\
\hline May 2014 & $\begin{array}{l}\text { National elections are held and the Bharatiya Janata Party (BJP), and its } \\
\text { alliance partners, win a majority of 543 seats in the Lok Sabha of the } \\
\text { Indian Parliament. }\end{array}$ \\
\hline $3 / 6 / 2014$ & $\begin{array}{l}\text { An Intelligence Bureau (IB) report is leaked targeting the role of } \\
\text { foreign-funded INGOs in India. It accuses INGOs of 'anti-national' } \\
\text { activities detrimental to India's economic growth and development } \\
\text { plans. }\end{array}$ \\
\hline $9 / 6 / 2014$ & $\begin{array}{l}\text { A second IB report is leaked targeting GPIN in particular. It focuses on } \\
\text { GPIN's campaigns on coal, nuclear and genetically modified foods since } \\
\text { 2011. It targets GPIN's organisational structures by questioning the } \\
\text { interaction between their global and local agencies in India. }\end{array}$ \\
\hline $13 / 6 / 2014$ & $\begin{array}{l}\text { Gol asks the Reserve Bank of India to seek a 'prior permission', as } \\
\text { stipulated in the FCRA, before transferring funds from Greenpeace } \\
\text { International (GPI) and the ClimateWorks Foundation into GPIN's bank } \\
\text { account. }\end{array}$ \\
\hline
\end{tabular}




\begin{tabular}{|c|c|}
\hline $23 / 6 / 2014$ & $\begin{array}{l}\text { GPI transfers Euros } 235,000 \text { to the FCRA bank account of GPIN (aka } \\
\text { Greenpeace India Society) via the IDBI Bank, Chennai. The amount was } \\
\text { not credited to their account and no explanation given. }\end{array}$ \\
\hline $27 / 08 / 2014$ & $\begin{array}{l}\text { GPIN files a writ petition against the GoI (MHA) as its FCRA bank } \\
\text { account has not been credited with the funds from its international } \\
\text { donors. }\end{array}$ \\
\hline $21 / 10 / 2014$ & $\begin{array}{l}\text { The Coal Mines (Special Provisions) Ordinance } 2014 \text { issued by the } \\
\text { President of India. It provides for allocation of coal mines and vesting } \\
\text { of rights relating to land and mine infrastructure. Emphasises energy } \\
\text { security and impact on core sectors. }\end{array}$ \\
\hline $10 / 12 / 2014$ & $\begin{array}{l}\text { The Coal Mines (Special Provisions) Bill } 2014 \text { introduced in the Lok } \\
\text { Sabha by the Minister of Coal. The Bill replaces the Coal Mines (Special } \\
\text { Provisions) Ordinance 2014. }\end{array}$ \\
\hline $11 / 01 / 2015$ & $\begin{array}{l}\text { Immigration authorities at New Delhi airport prevent a GPIN activist, } \\
\text { Priya Pillai, from boarding a flight to London where she had scheduled } \\
\text { to talk about her Mahan campaign work before British Members of } \\
\text { Parliament. }\end{array}$ \\
\hline $20 / 01 / 2015$ & $\begin{array}{l}\text { Delhi High Court orders that GPIN can access its FCRA bank account } \\
\text { and that its international funds previously blocked should be credited } \\
\text { to their account. }\end{array}$ \\
\hline $12 / 03 / 2015$ & $\begin{array}{l}\text { A landmark judgement by the Delhi High Court rules in favour of Priya } \\
\text { Pillai in her petition against the GoI. }\end{array}$ \\
\hline $30 / 03 / 2015$ & $\begin{array}{l}\text { The Coal Mines (Special Provisions) Act } 2015 \text { is adopted in the Indian } \\
\text { Parliament securing continuity in domestic production and mining of } \\
\text { coal. }\end{array}$ \\
\hline 09/04/2015 & $\begin{array}{l}\text { GoI suspends the registration of GPIN under FCRA } 2010 \text { for a period of } \\
180 \text { days. }\end{array}$ \\
\hline $15 / 05 / 2018$ & Delhi High Court accepts GPIN's writ petition; tells MHA to respond. \\
\hline $27 / 05 / 2015$ & $\begin{array}{l}\text { Delhi High Court directs the MHA to unblock two GPIN domestic bank } \\
\text { accounts pending adjudication of the writ petition. }\end{array}$ \\
\hline
\end{tabular}




\begin{tabular}{|c|c|}
\hline $16 / 06 / 2015$ & $\begin{array}{l}\text { Tamil Nadu Registrar Office issues a 'show cause' notice to GPIN } \\
\text { regarding irregularity in their filing of SRA records relating to their SRA } \\
\text { registration. }\end{array}$ \\
\hline $03 / 07 / 2015$ & $\begin{array}{l}\text { GPIN responds to the District Registrar with a detailed letter clarifying } \\
\text { its adherence to SRA rules. }\end{array}$ \\
\hline $04 / 08 / 2015$ & $\begin{array}{l}\text { GPIN files a writ petition in Madras High Court to challenge the 'show } \\
\text { cause' notice and charges issued by the District Registrar of Chennai. }\end{array}$ \\
\hline 02/09/2015 & GoI cancels GPIN's permanent FCRA registration. \\
\hline $4 / 11 / 2015$ & Tamil Nadu Registrar of Societies cancels GPIN's SRA registration. \\
\hline $20 / 11 / 2015$ & $\begin{array}{l}\text { Madras High Court suspends the cancellation of GPIN's SRA } \\
\text { registration. GPIN avoids having to close down. }\end{array}$ \\
\hline
\end{tabular}

